\title{
Youth bulge and demographic dividend in Nigeria
}

\author{
Oluwasola E. Omoju \\ Research Division, National Institute for Legislative Studies, National Assembly, Abuja, Nigeria \\ +234 8038537523; shollcy@yahoo.co.uk \\ Terfa W. Abraham \\ Research Division, National Institute for Legislative Studies, National Assembly, Abuja, Nigeria \\ +234 8062091306; Iorenzcurve@yahoo.com
}

\begin{abstract}
This paper examines the possibility of the demographic dividend in Nigeria. It investigates the role of youth empowerment in the attainment of the demographic dividend. It identifies the challenges facing a typical Nigerian youth and the various ways of investing in the youth bulge. It finds that the challenges facing the Nigerian youth ranges from the problem of youth unemployment, limited access to educational and lack of economic opportunities, lack of access to basic education, high HIV prevalence rate to high poverty rate. It posits that contrary to expectations, increase in the population of the youth may undermine development if the challenges facing the youths are not addressed. The paper recommends that the government should create employment and economic opportunities, provide educational and health facilities, and combat poverty in order to ensure that the bulging youth population translates into economic growth and development.
\end{abstract}

Keywords: Youth bulge, youth empowerment, demographic dividend, economic development, Nigeria

\section{Résumé}

Ce document examine la possibilité de le dividende démographique au Nigeria. Il étudie le rôle de l'autonomisation des jeunes dans la réalisation du dividende démographique. II identifie les défis auxquels fait face un jeune Nigérian typique et les différentes façons d'investir dans l'explosion de la jeunesse. Il estime que les défis auxquels sont confrontés les plages de jeunes nigérians du problème de chômage des jeunes, l'accès limité à l'éducation et le manque d'opportunités économiques, le manque d'accès à l'éducation de base, le taux de prévalence du VIH est élevée au taux de pauvreté élevé. Il postule que, contrairement aux attentes, l'augmentation de la population de la jeunesse peut compromettre le développement si les défis auxquels font face les jeunes ne sont pas abordées. Le document recommande que le gouvernement devrait créer des emplois et de possibilités économiques, aux possibilités d'enseignement et de santé et de lutte contre la pauvreté afin de s'assurer que la population des jeunes bombé se traduit par la croissance économique et le développement.

Mots-clés: jeunesse Ardennes, l'empowerment des jeunes, dividende démographique, le développement économique, le Nigeria

\subsection{Introduction}

Economists have foreseen that Nigeria is expected to experience a youth bulge - an increase in the population of the youth relative to other age groups (Bloom and Humair, 20I0; Reed and Mberu, 20II). The general expectation was that rising ratio of youth population relative to other age groups would stimulate economic growth and development, otherwise known as demographic dividend. The youth bulge has the potential to propel economic growth and human development. However, this is not automatic (Olaniyan, Soyibo and Lawanson, 2012). For example, the high rate of risky behavior associated with the youth population has led many to conclude that the youth bulge could be a problem rather than an asset to the society (Skogan, 1986; Urdal, 2006).

In recent years, various governments have devised new approaches to addressing the challenges facing the youth as well as harnessing their potential. This has led to the recognition of the need to empower the youth in order to realize the benefits of the demographic dividend. Against this backdrop, the major questions this paper answers are: What are the major challenges facing the Nigerian youth today? What role does youth empowerment play in realizing demographic dividend? How has the government of other countries, particularly in the South-East Asia, empowered and invested in their youth? How can the Nigerian government invest in the youth bulge?

The main objective of this paper is to theoretically examine the role of youth empowerment in the attainment of the demographic dividend. Specifically, it identifies the challenges facing the youth, investi- 
gate how countries in South-East Asia invested in their youth bulge and how government can invest in the youth bulge to enhance the attainment of demographic dividend in Nigeria.

The paper is divided into four sections. The first section is the introduction. The second section is the literature review and theoretical framework, which presents an overview of youth bulge and demographic dividend and their underlying mechanisms. Discussion of key issues is the focus on section three. In it, we examine the challenges facing the youth in Nigeria, the potential benefits and consequences of the youth bulge, and experiences of other countries in managing their youth bulge. The final section provides the conclusion and recommendation.

\subsection{Literature review and theoretical framework}

\subsection{Youth bulge and demographical dividend: an overview}

The term "youth bulge" was coined by a German social scientist, Gunnar Heinsohn in the mid-1990s. It is a common phenomenon in many developing countries. It is used to describe a situation where there is an increase in the proportion of the youth population relative to other age groups. A country is said to incur a youth bulge when the population of the youth group is larger than all other age groups, which is attributed to an increased birth rate, declining infant mortality and overall improvement in health.

There is evidence that the youth bulge is valid in sub-Saharan Africa, as the region's youth population has been increasing far more than it is experienced in other regions of the world. This is supported by the World Bank, which claimed that over 200 million people, representing about $20 \%$ of the population, $40 \%$ of the work force, and $60 \%$ of the unemployed in Africa, falls within the youthful population (Agbor, Taiwo and Smith, 20I2). This means that more and more youth are not absorbed into the economy.

Statistics from the Population Bureau confirms the problem of the youth bulge in Africa. Fig. I shows that as at 2010 , the proportion of the young population in Africa is higher than in developed and several developing countries. As at 2010, the proportion of child population (0-14) and youth population (15-29) in the total population in the developed region stood at $15 \%$ and $20 \%$ respectively. In the developing regions, the proportion of child and youth population was $29 \%$ and $27 \%$ in 2010 . In the case of Africa, child and youth population accounts for $40 \%$ and $28 \%$ respectively. In effect, the proportion of the young population in Africa's total popula- tion is about $70 \%$. Similarly, the youthful population as a percentage of projected population in the 15-29 age range shows that by 2050 Africa will have the highest share of young people in the world (Fig.2).

The demographic dividend on the other hand, is the socio-economic opportunity that emerges in a country as fertility rates decline which can lead to economic growth and development when supported with appropriate and effective public policies. It occurs when a falling birth rate changes the age distribution, so that fewer resources are required to meet the needs of the dependent population of children and old people and resources are mobilized for investment in economic growth and human development.

The concept of demographic dividend is borne out of the notion that as mortality rates reduces, people would desire to have fewer children, and there would be an increase in the population of working adults relative to the other population groups, which would result in economic growth. The increase in the number of the working-age adults lays the foundation for demographic dividend. The reduction in the number of children allows families to invest more in their children's education and health, increasing skills and human capital. Besides, working adults have the opportunity to save more for retirement as dependency ratio reduces. Women could also work as the time used for child rearing is reduced, thereby boosting the labour force. These developments are expected to have positive effects on the economy; although a new study by Bloom et al. (2009) shows that lower fertility can also lead to higher inequality in the short term.

There is an obvious relationship between fertility rate and development. Families with large number of children tend to be poorer and vice-versa (NBS, 2006). Similarly, countries with high fertility rates often tend to be poorer. For instance, countries with the highest fertility rates such as Mali, Niger and Chad are among the poorest in the world. Also, countries with low fertility rates tend to be rich. Using Demographic and Health Survey data for 60 countries, Bloom et al. (2009) found that the youth dependency ratio is lowest in the richest countries, next lowest in the next richest countries, and so on to the poorest countries, which has the highest youth dependency ratio. Also, demographic dividend has been argued to account for between 25 and $40 \%$ of the economic transformation experienced by the East Asian Tigers (Bloom, Canning and Malaney, 2000; Bloom and Williamson, 1998). On the other hand, Bloom and Sachs (1998) posited that population explosion has contributed to economic stagnation in most of sub-Saharan African countries. A recent study by Ashraf, Weil and Wilde (20II) 
shows that a decrease in Nigeria's fertility rate by one child per woman would boost GDP per head by I3\% over 20 years, due largely to the dependency effect. In the next section, the core challenges facing the youth population are discussed.

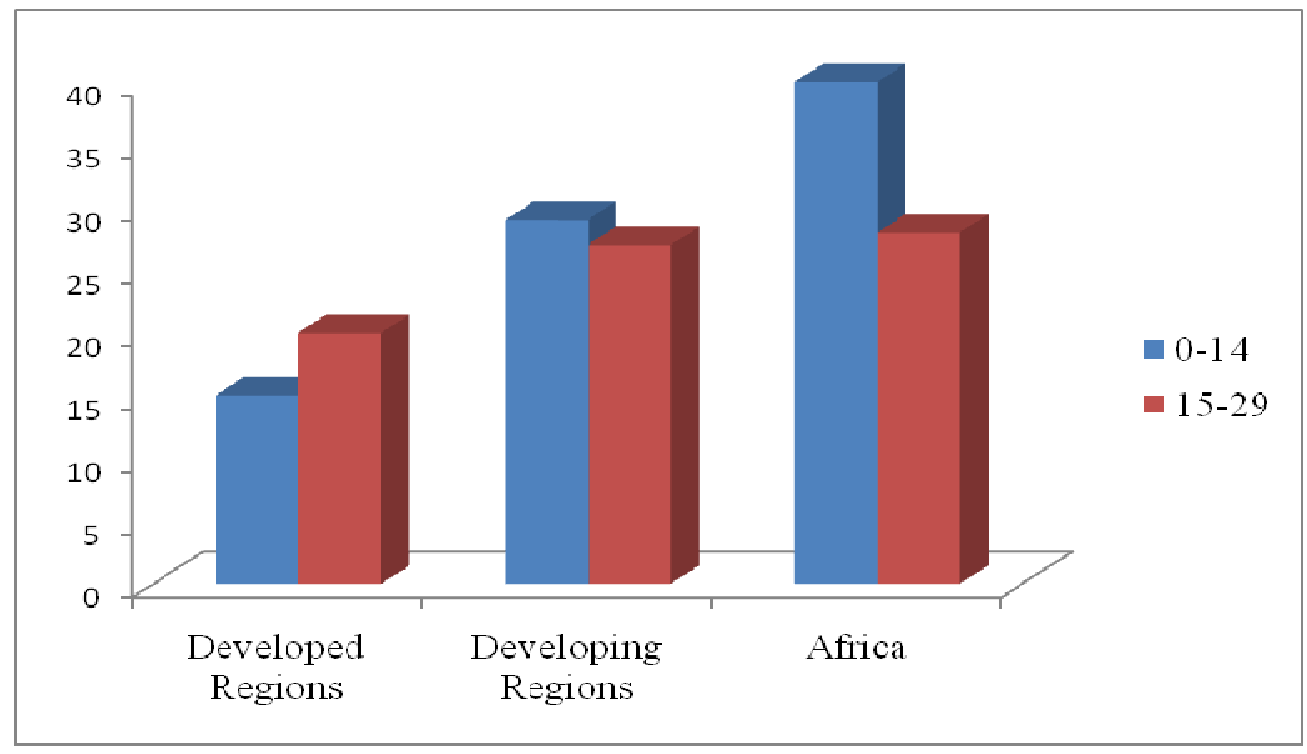

Fig. 1 Proportion of young population as $\%$ of total population, 2010

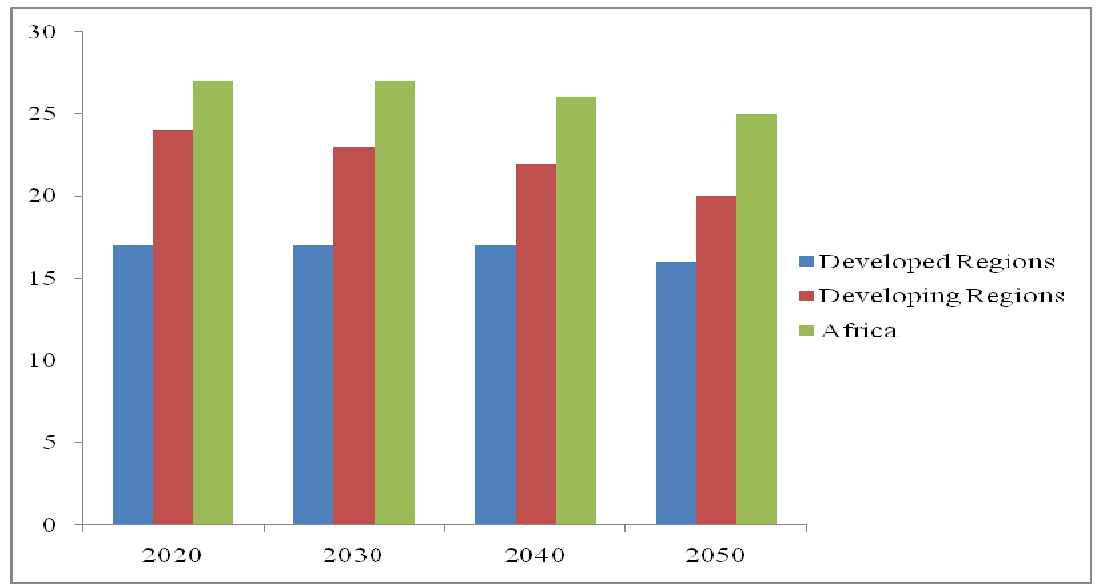

Fig. 2: Youthful population as \% of projected population in the 15-29 age range, Country Aggregates

Source: Author's calculations based on data from UN, Department of Economic and Social Affairs, Population Division (2011), World Population Prospects: The 2010 Revision. Medium fertility scenario is used for the 2050 projections. 


\subsection{Discussion}

\subsection{Challenges facing the youth in Nigeria}

\subsubsection{Socio-economic and political environment}

The socio-economic and political environment in Nigeria poses a great challenge to the youth. Key economic and social indicators point to the fragility of the Nigerian economy and poor well being of the people. After over fifty years of independence, the economy is still dependent on the primary sector. There is high level of indebtedness, unemployment, poverty, infant and maternal mortality, illiteracy, and an entrenched culture of corruption. The absence of basic infrastructure has left majority of Nigerians with no access to basic services such as water supply, electricity, sanitation, housing, among other important basic means of survival. The situation has been worsened by the poor governance structures in place in the country (Aiyede, 2002). Thus, after over ten years of democratic rule, the political landscape is still marked by exclusion of most people from governance, lack of accountability and transparency, and corruption, all of which have implication for the meaningful participation of the youth population in the economic and governance arrangements of the country.

\subsubsection{Poverty}

The poverty level in Nigeria has witnessed a substantial upward swing over time given statistics report in the NBS 2006 Report. As at 1980, poverty level in Nigeria was $28.1 \%$. The poverty level increased to $46.3 \%$ in 1985 , before plunging to $42.7 \%$ in 1992. In 1996, the poverty rate increased drastically to $66.9 \%$. However, due to the various poverty-alleviating measures initiated by the government at the beginning of the new democratic dispensation, the national poverty rate fell by $12.5 \%$. However, between 2004 and 2010, the poverty level rose by $14.6 \%$. Similarly, the proportion of the population living in poverty has consistently increased from 1980 to 2010 . In 1980, 18\% of the population was reported as living in poverty, but the rate doubled in 1985. Between 1985 and 2004, the population under poverty doubled, increasing from $35 \%$ in 2004 to $69 \%$ in 2004 . The trend is worsened by the increasing rate of unemployment, lack of basic infrastructure, political corruption, and poor economic policies. The prevailing situation has forced many Nigerian youths into social vices such as drug trafficking, kidnapping, fraud, prostitution, crime, and other illegitimate activities.

\subsubsection{Unemployment}

In addition to the numerous challenges which include high level of poverty, terrorism and militancy, and corruption which face Nigeria, youth unemployment remains a challenge to the policy makers and the political leadership. Youth unemployment has been described as a major problem and a denominator of most of the other problems faced by the country. According to the National Bureau of Statistics (NBS), the national unemployment rate in Nigeria in 2005 was $11.90 \%$. This rose sharply to $19.7 \%$ in 2008; and in 2010 and 2011 , the figures were $21.1 \%$ and $23.9 \%$, respectively.

Although, youth unemployment has long been a problem in Nigeria, it assumed a higher dimension during and after the global economic meltdown. The lingering financial crisis coupled with the poor performance of the manufacturing sector due in part, to poor infrastructure, exacerbated the situation. The neglect of the agricultural sector, rural-urban migration, poor business environment and the moribund state of the industrial sector have also contributed immensely to the problem.

A more worrisome trend in the unemployment situation in Nigeria is the high rate of graduate unemployment in recent years. Okafor (20I I) stated that about 64 million youths were unemployed or underemployed in the country, while noting that in 2008, only $10 \%$ of Nigerian graduates got paid employment in the country. According to another study, graduate unemployment increased from $25.6 \%$ in 2003 to $40.3 \%$ in 2009 (Akinyemi, Ofem and Ikuenomore, 2012).

\subsubsection{Lack of educational opportunities}

Education and human capital development are vital to economic growth and poverty reduction. Besides, they are critical to the realization of demographic dividend because they easily translate to economic growth and development. However, educational opportunities in Nigeria are unequally distributed. Poor youths have less educational opportunities than their richer counterparts. Similarly, some socio-economic and cultural factors favour boys ahead of girls in primary and secondary school enrollment, especially in the northern part of the country while economic hardship often force them out of school in other parts of the country.

According to the NBS (2009), 34\% and 20\% of adult and youth respectively could not read or write in 2008. In the same year, Imo State has the highest youth literacy rates at $99.2 \%$, followed by Lagos State at 99\%; while Lagos State has the highest adult literacy rate at $95 \%$. On the other hand, Bauchi State has the lowest youth literacy rate at $48.9 \%$ while Katsina State has the lowest adult literacy rate at $29.6 \%$. Only 3,720,789 children, representing $37.9 \%$ of primary school enrolment, have access to junior secondary school education in Nigeria in 
2008. The South West reported the highest figure of $24.4 \%$ while the South South recorded the lowest, II.5\%. Moreso, only very few proportion of secondary school leavers gain admission to higher institutions due to small number of tertiary institutions relative to the population of applicants. In all, fiscal crises, political instability, endemic poverty and high demographic pressure on the educational system have resulted in falling quality and limited access to education (Odaga and Heeveld, 1995). Furthermore, the available educational infrastructure is inadequate to provide access to a functional and qualitative education for all Nigerian children and youths. Qualified Nigerian youths have also been denied access to quality education due to "equitydriven" government policies such as "catchment areas" and "educationally less advantaged states".

The government has recently taken steps to increase the quality and access to education for the youth. The first is the introduction of the almajiri school system in Northern Nigeria to keep youths in the region off the street and provide them with quality education. Second, the Federal Government has established nine new federal universities to expand available spaces for qualified Nigerian youth to access university education. In addition, there are steps to ensure adequate funding and upgrade of the entire tertiary educational system with the main aim of expanding access to qualitative educational opportunities. However, despite efforts by the government to revamp the education sector and improve educational opportunities for the youth, there are still challenges that impede access to qualitative and effective education. These challenges include inadequate funding, corruption, poverty, incessant strike actions by university teachers, poor infrastructure and government policies.

\subsubsection{HIVIAIDS and reproductive health risks}

Young people the world over face serious reproductive health risks and health problems associated with inadequate healthcare services, illiteracy and poverty. The lack of sexual health services and education places the youth at a high risk of unwanted pregnancy, abortion and sexually transmitted diseases including HIV/AIDS. Nigeria's HIV/AIDS prevalence rate ranges from $10.6 \%$ in Benue State to $1.0 \%$ in Ekiti State, while the aggregate prevalence rate stands at $4.6 \%$ in 2008 (NBS, 2009). This is relatively small in comparison to some Southern African nations. However, the country accounts for about one-tenth of the world's HIV/AIDS infected persons with 3.5 million infected people, the largest HIV-positive population in Africa after South Africa (UNAIDS 200I, cited in Dagne, 2006). As the population increases, HIV infection rate will likely increase, especially among youths, if urgent steps are not taken to arrest the drift. The lack of educational and economic opportunities for the youth as well as the high level of poverty may aggravate the problem of HIV/AIDS in Nigeria.

Apart from these identified problems, an average youth in Nigeria is faced with challenges of inadequate parental care, moral decadence, religious fanaticism, cultism, examinational practices, indiscipline, breakdown of family and cultural values, overexposure to negative western cultures, over-exposure to the culture of corruption, ethnicity and lack of national consciousness, abuse of technology and political manipulation of youths (Aiyede, 2002; Oviawe, 2010).

\subsection{Youth bulge, empowerment and demographic dividend}

Leveraging the youth bulge productively and effectively could lead to prolonged economic growth and substantial poverty reduction. The youth bulge presents great potentials for economic opportunities for Nigeria through active participation in the labour market and expansion of markets. It could also be a source of savings. The youth population can also engender innovation and support governance and political reforms (Agbor, Taiwo and Smith, 20I2). If the increase in the number of the working population can be fully absorbed into productive activities, ceteris paribus, average per capita disposable income will increase. Thus, the youth bulge will result in a demographic dividend. Increased number of employed youths also offers great opportunities for skills transfer, which directly impact human capital accumulation and long term economic growth and development. Also, a youthful and employed population will directly contribute to reduction in inequality, thereby enhancing the prospects for social coherence and stability, which are key ingredients for growth and development (Zille and Benjamin, $20 \mathrm{II})$. However, if there are no economic opportunities for the large number of the youth population, the youth bulge could result in a demographic bomb, because a large number of jobless youth could become a potential source of social and political instability, with dire consequences for economic development.

The effect of demographic dividend on economic growth is transmitted through increases in labour supply, savings rates, human capital and domestic demand. It is centered on the assumption that increase in population of the working group relative to other age group will result in increase in labour supply, savings, investment, human capital development, domestic demand and ultimately economic growth. This is because there will be reduc- 
tion in dependency ratio as families spend less on children's education, health and other needs, thereby creating opportunities for savings and investment. However, the manifestation of the demographic dividend depends on effective and appropriate complementary public policies.

To enjoy the benefit of the demographic dividend, the government needs to put in place appropriate policies. Most importantly, they need to invest in youth empowerment and development. Increase in the population of the working class without adequate provision for their absorption into the labour force may not result in economic growth. The possibility of the demographic dividend resulting in economic growth and human development is dependent on the initiation and sustenance of effective complementary public policies, especially those relating to youth empowerment.

Improving access to health facilities is crucial to the effective translation of the demographic dividend to economic growth and human development. Evidences abound that improved health facilitates productivity (Bloom, Canning and Malaney, 2000). An increase in youth population relative to other age groups may not result into productivity if the youth are affected by poor health. It points to the importance of appropriate health policies to ensure improved productivity in the course of the demographic dividend. Family planning services aimed at reducing unwanted pregnancies could facilitate the development impact of the demographic dividend.

Policies aimed at reducing the level of poverty and youth unemployment are also vital to the attainment of the benefits of the demographic dividend. According to Olaleye (2010), youth empowerment helps to reduce the level of poverty and the tendencies for young people to engage in criminal activities. Initiatives to improve human resource capabilities and create jobs are essential to absorb the large number of youths entering the labour force. This could be achieved by creating an enabling environment for the private sector through appropriate investment in infrastructure and initiation of good macroeconomic policies. Besides, developing a culture of entrepreneurship among the youth can help to reduce the level of unemployment and poverty in the country.

According to Obadan and Odusola (200I), the possibility of Nigeria promoting inclusive development and improving the welfare of the people is bleak if efforts are not put in place to stem the tide of youth unemployment. Besides, education and human capital development have long been recognized as pivotal to economic development and poverty alleviation. However, in a country such as Nigeria where high levels of youth and graduate unemployment exist, the attainment of development objectives may well be considered an illusion. This is because education and human capital are not translated into productivity, leaving demographic dividend to be of no effect. The implications of these are high level of poverty, crime rate, drug trafficking, hostage taking, youth restiveness, terrorism and other social vices. This problem could also be a clog in Nigeria's wheel to actualizing the objectives of the transformation agenda, the MDGs and Vision 20: 2020.

Moreover, to ensure that demographic dividend is sustainable, good public policies that would promote the effective transmission of the demographic dividend into economic growth must be initiated, even though they take time to establish and take effect (Ross, 2004). Therefore, investments in education, health, and job creation are vital. This is in line with Ruhl (20II) who argue that in order to empower Nigerian youth and make the current youth bulge beneficial, they should be engaged through the ICT, entertainment, hospitality and agribusiness sector.

The youth bulge could also be associated with violence and conflict. Following the youth explosion that has been widely characterized as the Arab Spring of 20II, security experts have considered sub-Saharan Africa region the next stop for political up-risings. This is as a result of the increase in the population of educated youths confronted with rising unemployment and lack of economic opportunities (AfDB, 2012 and Ogujiuba, Ogbonnaya and Abraham, 20I3). Unemployment, poverty, and recently, rising prices present a serious challenge to the youth in the region. It is believed that a surplus of young people, especially men, who cannot find opportunities in the society, may be forced to embark on violence. Even in the absence of largescale political revolts like those of the Arab Spring, mass youth unemployment could result in lost human capital and increased crime and other social vices. This school of thought has been buttressed by experiences of some West African countries such as Liberia, Sierra Leone, Guinea and Cote d'Ivoire (Atta-Asamoah and Kwesi-Aning, 20II). The spate of terrorist activities and kidnapping in the Northern and Southern parts of Nigeria respectively has also led credence to the arguement of this school of thought. Therefore, the youth bulge in Nigeria is a frightening challenge to the country's development, and thus requires careful and swift interventions. The government must engender efforts to harness the opportunities in the youth bulge and minimize its risks. 


\subsection{Confronting Nigeria's youth bulge: experiences and policy options}

The experience of the East Asian Tigers provides a model in the management of the youth bulge. The youth bulge experienced by these countries between 1965 and 1990 was effectively managed through better education and increased job opportunities, leading to impressive economic growth and development. Some policy analysts have attributed over $40 \%$ of the phenomenal growth experienced by these countries to the positive effect of the youth bulge, alongside radical trade policies and human capital development (Bloom and Canning, 2006).

Some countries in East Asia have been successful in converting their youth bulge into demographic dividend. Dependency ratio has declined significantly in South Korea in the past 40 years. The country has also kept youth unemployment below $12 \%$ and in single-digit in recent years. This has been followed by a dramatic increase in GDP growth and average wages (Lin, 20I2). Similarly, due to versatile economic reforms since the late 1970s, China has been able to generate million of new jobs while also relocating young workers from lower productivity agricultural activities to higher productivity manufacturing.

Cambodia has the highest proportion of young people in South-East Asia. In her case, it was discovered that the challenges facing the youth are linked to access to education, skill training and health care. Most school leavers are ill-equipped to enter the labour market. There are also concerns in the areas of reproductive health and STIs including HIV. To address this challenge, the key stakeholders, involving the government, civil society, and youth organisations were engaged in the development of the National Policy on Youth Development. The policy is a cross-sectoral approach, taking cognizance of the various needs of the youth. Similarly, countries in the Pacific region focused extensively on multi-sectoral approach, with emphasis on skills training, volunteerism and the development of sustainable livelihoods. Attention is placed particularly on integrating youth into the traditional sector of agriculture and entrepreneurship. Also, the strategy recommends that young entrepreneur are given incentives and supports, including bank loan schemes, business small grant schemes, tax breaks, and establishment of technical advisory and support units (Asia-Pacific Interagency Group, 20I I).

To curtail the possibility of the youth-led Arab Spring in sub-Saharan Africa, the sub-region's governments at the 201I African Union Summit, in Equatorial Guinea, reached a consensus to accelerate the 2009-2018 Decade of Youth Action Plan. They noted that given the high level of unemploy- ment in the region, the youth bulge was an impending threat to stability (ILO, 20I2).

Several youth-oriented goals have however been set in order to avert this impending disaster. The AU aims to reduce youth unemployment by $2 \%$ per year over the next five years as contained in the Plan; focus on vocational and technical education and training; and to provide adequate funding to advance the youth agenda (Africa Union, 20II). These decision and goals may not be realistic if appropriate and pragmatic actions are not taken at the national levels.

There is need for governments in the sub-region to begin to develop strategies to upgrade the skills and competencies of the youth in line with the each country's comparative advantage and sectoral prospects. For example, the Kenyan Government in its Vision 2030 has prioritised information technology (IT) enabled services, as a strategy for reducing youth unemployment and enhancing economic growth. The initiative is expected to provide over 10,000 jobs in five years (Government of Kenya, 2007). Therefore, policy makers in the region must identify sectors with potentials for job creation and develop the skills of the youth around such sectors.

Available evidence suggests that majority of the youth in sub-Saharan Africa are involved in selfemployment in the informal and agricultural sectors. According to Adams (2008), 94\% of the general population in Mali, $74 \%$ in Ethiopia and $31 \%$ in South Africa are engaged in the informal and agricultural sector. Unfortunately, the governments in the region have not paid particular attention and given priority to agriculture and development of the informal sector. To successfully manage the youth bulge to enhance socio-economic development in subSaharan Africa, governments in the region should create an enabling environment for youth to participate in the labour market. They should focus on promoting conditions that are favourable to the development of the agricultural and informal sectors. These sectors possess enormous potential for youth employment and wealth creation, and typically require low formal skills. Besides, the problem of shortage of infrastructural facilities, particularly power supply that could aid small and medium-scale enterprises should be appropriately and adequately addressed. Policy makers should also facilitate means to ensure that young entrepreneurs have access to credit. This can be done by providing incentives for financial institutions to provide funds to selfemployed youths.

Institutional factors that serve as barriers to youth integration into the economy should be removed. In most sub-Saharan countries, youth and women have restricted access to land due to land 
use rights and laws, thereby limiting their productive prospects in the agricultural sector. Similarly, in Nigeria, institution such as the National Youth Service Corp (NYSC) and the principle of federal character have disguisedly fuel the problem of graduate unemployment as private companies take advantage of the scheme to employ youth corp members on continuous basis instead of employing substantive staffs.

\subsection{Conclusion and recommendations}

Half of Nigeria's population is youthful. Addressing the critical challenges facing them is an urgent priority if social and economic development efforts are to succeed. Every country is expected to benefit from increase in the population of the working group relative to other age groups. Nigeria and some other sub-Saharan African countries are starting the demographic transition and are expected to witness a significant rise in the population of young adults and the economic benefits associated with it.

The paper has argued that the challenges facing the Nigerian youth range from the problem of youth unemployment, lack of economic opportunities, lack of access to basic education, high HIV prevalence rate to high poverty rate. It also found that contrary to expectations, increase in the population of the youth may undermine development if the challenges facing the youths are not addressed. This paper recommends that the government should formulate and sustain policies that would address the socio-economic challenges facing the youth. Investments that meet young people's needs for health care, education and economic opportunities are essential. Creating employment and economic opportunities, providing health and educational facilities and combating poverty are critical elements of ensuring that the bulging youth population translates into economic growth and development.

\section{References}

Adams, A. 2008. "Skills development in the informal sector of sub-Saharan Africa”, Washington, DC:

The World Bank.

AfDB 2012. "Job, justice and the Arab Spring: Inclusive growth in North Africa", Tunis: African Development Bank Group.

Africa Union 201 I. "Decisions adopted during the 17 th African Union Summit held from 23rd June to July Ist, 20I I in Malabo, Equitorial Guinea", Retrieved online from http://www.au.int/en/sites/ default/files/I 7th\%20_SUMMIT_DECISIONS_DECLĀRATIONS__and_RESOLUT IONS_-_eng\%20FINAL.pdf

Agbor, J., Taiwo, O., and Smith, J. 2012. "SubSaharan Africa's youth bulge: A demographic dividend or disaster"? Africa Growth Initiative, The Brookings Institution, 9- I I.

Aiyede, E.R. 2002. "The state, values and development: Towards re-orientating the Nigerian youth for positive leadership". Retrieved online from http://www.cbaac77.com/archives/ pdf/Dr.\%20Rem_Ayede.pdf.

Akinyemi, S., Ofem, I.B. and Ikeunomore, S. 2012. "Graduate turnout and graduate employment in Nigeria”. International Journal of Humanities and Social Sciences 2, (14): 257-265.

Ashraf, Q.H., Weil, D.N. and Wilde, J. 20I I. "The effect of interventions to reduce fertility on economic growth". Brown University Department of Economics Working Papers No. $2011-14$.

Asia-Pacific Interagency Group 201 I. "Investing in youth policy: Sharing good practices to advance policy development for young people in the AsiaPacific region", Retrieved from http:// www.investinginyouthpolicy.com/ Investing In Youth Policy.pdf

Atta-Asamoah, A. and Kwesi-Aning, E. $201 \mathrm{I}$. "Demography, environment and conflict in West Africa" in T. Jaye., D. Garuba and S. Amadi (eds), ECOWAS \& the dynamics of conflict and peace building, CODESRIA, Dakar.

Bloom, D.E., Canning, D., Fink, G. and Finlay, J. 2009. "Fertility, female labour force participation, and the demographic dividend", Journal of Economic Growth 14, (2): 79-101.

Bloom, D.E., Canning, D. and Malaney, P. 2000. "Demographic change and economic growth in Asia, Population and Development Review 26: 257-290.

Bloom, D.E. and Humair, S. 2010. "Economic development in Nigeria: A demographic perspective", Committee on African Studies, Harvard Africa Seminar, April 13.

Bloom, D.E. and Williamson, J.G. 1998.

"Demographic transitions and economic miracles in emerging Asia", World Bank Economic Review 12: 419 - 455.

Bloom, D.E. and Sachs, J.D. 1998. "Geography, demography, and economic growth in Africa", Brookings Papers on Economic Activity 2: 207273.

Dagne, T. 2006. "Nigeria in political transition”, Congressional Research Services Report for Congress, June $28^{\text {th }}$.

Government of Kenya 2007. "Kenya Vision 2030: A globally competitive and prosperous Kenya", Retrieved online from http://www.kilimo.go.ke/ kilimo_docs/pdf/Kenya_VISION_2030-final.pdf

ILO 2012. "Youth employment intervention in Africa: A mapping report of the employment and 
labour sub-cluster of the Regional Coordination Mechanism (RCM) for Africa", Geneva: International Labour Organisation.

Jimenez, E.Y. and Murthi, M. 2006. "Investing in the youth bulge", Finance and Development 43, (3), Washington, DC.: International Monetary Fund.

Lin, J.Y. 2012. "Youth bulge: A demographic dividend or a demographic bomb in developing countries", The World Bank. Retrieved from http:// blogs.worldbank.org/developmenttalk/youthbulge-a-demographic-dividend-or-ademographic-bomb-in-developing-countries.

NBS 2006. "Core welfare indicators questionnaire survey", Abuja: National Bureau of Statistics.

NBS 2009. "Social statistics in Nigeria". Abuja: National Bureau of Statistics.

Obadan, M.I. and Odusola, A.F. 200I. "Productivity and unemployment in Nigeria" Ibadan: NCEMA

Odaga, A. and Heeveld, W. 1995. "Girls and schools in sub-Saharan Africa", World Bank Technical Paper No. 298, Washington, DC.: World Bank.

Ogujiuba, K., Ogbonnaya, U.M. and Abraham, T.W. 2013. "Comparative analysis of Arab Spring determinants and security implications for Nigeria”, African Security Review 22, (4): I-I4.

Okafor, E.E. 20I I. "Youth unemployment and implications for stability of democracy in Nigeria", Journal of Sustainable Development in Africa 13, (I): 358-373.

Olaleye, Y.L. 2010. "Youth empowerment as a strategy for reducing crime in the society", European Journal of Social Sciences 15, (2): 270277.

Olaniyan, O., Soyibo, A. and Lawanson, A.O. 2012. "Demographic transition, demographic dividend and economic growth in Nigeria", African Population Studies 26, (2): I59- 176.
Oviawe, J.I. 20 I0. "Repositioning Nigerian youths for economic empowerment through entrepreneurship education", European Journal of Educational Studies 2, (2): I I3- I I8.

Population Reference Bureau 2009. "World Population Data Sheet 2009", Washington, DC: Population Reference Bureau.

Reed, H.E. and Mberu, B. 20II. Demographic dividend or demographic obstacle? How ethnic, religious, and regional fertility differentials keep the TFR high in Nigeria", Paper presented at the Population Association of America 20 I I Annual Meeting Program, held at Marriot Wardman Park, Washington, between March $3 \mathrm{I}$ and April 2.

Ross, J. 2004. "Understanding the demographic dividend”, Washington, DC.: Policy Project. September.

Ruhl, O. 20I I. "Nigeria's youth: Turning challenges into opportunity", A Convocation lecture Presented on the events of the 23rd Convocation of Federal University of Technology Owerri, Imo State Nigeria.

Skogan, W. 1986. "Fear of crime and neighbourhood change", in Reiss, A. J. Jr. and Tonry, M. (eds.), Communities and Crime 8: 163-175, Chicago: University of Chicago Press.

Sommers, M. 20I I. "Governance, security and culture: Assessing Africa's youth bulge", International Journal of Conflict and Violence 5, (2).

Urdal, H. 2006. "A clash of generations? Youth bulges and political violence", International Studies Quarterly 50, (3): 607-629.

Zille, P. and Benjamin, J. 20I I. “Africa's youth bulge boon or bust? Policy choices to assist unemployed youths", Discussion Paper No. 8, Johannesburg: The Brenthurst Foundation. 